\title{
Studies on Feed Intake, Growth Performance and Economics of Broilers Fed Garlic Powder
}

\author{
R.B. Makwana ${ }^{1 *}$, S.S. Parikh ${ }^{1}$, B.D. Savaliya ${ }^{1}$, J.A. Chavda ${ }^{2}$, \\ C.N. Jadav ${ }^{1}$ and H.A. Patel ${ }^{3}$
}

${ }^{1}$ Cattle Breeding Farm, Junagadh Agricultural University, Junagadh- 362001, Gujarat, India

${ }^{2}$ College of Veterinary Science \& A. H., Junagadh Agricultural University, Junagadh-362001, Gujarat, India

${ }^{3}$ College of Veterinary Science \& A. H., Sardarkrushinagar Dantiwada Agricultural University Sardarkrushinagar-385506, India

*Corresponding author

\section{A B S T R A C T}

The present experiment was conducted to find out the effects of adding different levels $(0$, 0.1 and $0.5 \%$ ) of garlic (Allium sativum) powder to the basal experimental diet on the feed

Keywords

FCR, Feed Intake

(FI), Cobb-400,

garlic, growth

\section{Article Info}

Accepted:

15 July 2019

Available Online:

10 August 2019 intake, growth performance and economics of broiler chicks. One hundred and eighty $(n=180)$ day old unsexed white commercial broiler chicks (Cobb-400) were randomly distributed into three dietary treatments of 60 birds/dietary treatment and each treatment contained 4 replicates (15 birds/replicate). The dietary treatments were control $\left(\mathrm{T}_{1}\right.$-basal diet only), garlic powder supplemented at $0.1 \%\left(\mathrm{~T}_{2}\right)$ and $0.5 \%\left(\mathrm{~T}_{3}\right)$ in basal diet. Daily feed intake, weekly body weight and residue left over were recorded to calculate the feed conversion ratio. Results revealed that dietary supplementation of $0.1 \%$ garlic powder $\left(\mathrm{T}_{2}\right)$ significantly $(\mathrm{P}<0.001)$ improved body weight, body weight gain as compared to birds supplemented with $0.5 \%$ garlic powder $\left(\mathrm{T}_{3}\right)$ and control $\left(\mathrm{T}_{1}\right)$. Dietary supplementation of $0.1 \%$ garlic powder $\left(\mathrm{T}_{2}\right)$ significantly $(\mathrm{P}<0.05)$ improved feed intake and feed conversion ratio as compared to birds supplemented with $0.5 \%$ garlic powder $\left(\mathrm{T}_{3}\right)$ and control $\left(\mathrm{T}_{1}\right)$. Total cost $(₹) / \mathrm{kg}$ meat was reduced $(\mathrm{P}<0.001)$ in $0.1 \%$ garlic $\left(\mathrm{T}_{2}\right)$ as compared to $0.5 \%$ garlic $\left(\mathrm{T}_{3}\right)$ supplemented birds or control $\left(\mathrm{T}_{1}\right)$. Thus, dietary supplementation of $0.1 \%$ garlic had beneficial effect on growth performance and cost of production.

\section{Introduction}

Feeds containing no chemical additives are increasingly used in poultry nutrition. For this reason, herbs and natural feed additives i.e. garlic, fenugreek, thyme, etc. are being investigated as natural sources biologically important substances (Demir et al., 2003).
Garlic (Allium sativum) is bulbous vegetable, well known spice and medicinal plant. It contains organic sulphurius compounds such as aliin, allicin, ajoene, allylpropyl disulphide, diallyl trisulphide and sallilcisteine (Mansoub, 2011). Recent research works on garlic formulations as feed additives have shown encouraging results with regards to weight 
gain, feed efficiency, lowered mortality and increased livability in poultry birds (Karangiya et al., 2016). Hence, the present study was designed to study the potential of incorporating different levels of garlic as a growth promoter in commercial broilers.

\section{Materials and Methods}

Birds, ration, experimental design and place of work

One hundred and eighty $(\mathrm{n}=180)$ day old commercial broiler chicks (strain 'Cobb-400') were randomly distributed into three groups with 4 replicates of 15 birds in each group. Garlic bulbs used in trial was procured from local market then dried in hot air oven, dry bulbs were powdered in an electrical grinder and stored in air tight container at room temperature for use. Dietary treatments were $\mathrm{T}_{1}$ : Basal diet without garlic powder supplementation (Control), $\mathrm{T}_{2}$ : Basal diet with garlic powder supplementation $1 \mathrm{~g} / \mathrm{kg}$ of feed and $\mathrm{T}_{3}$ : Basal diet with garlic powder supplementation $5 \mathrm{~g} / \mathrm{kg}$ of feed. The basal diets were formulated as per the standards of NRC (1994). The research work was conducted for six weeks at private poultry farm of Dangia village, Dantiwada taluka, Banaskantha district of Gujarat, India.

\section{Observations Recorded}

\section{Body weight and body weight gain}

Body weight of the individual experimental chicks were recorded in the morning before feeding with the help of digital weighing balance at day old and thereafter at weekly interval till six weeks of age.

\section{Feed intake and feed conversion ration}

Feed consumption was measured by weighed quantity of feed offered to each group and at the end of week feed left over was weighed and recorded. On the basis of that average weekly feed intake and feed conversion ratio (FCR) was calculated.

\section{Mortality}

Broilers under study were routinely supervised for any ailment or death on day-to-day basis during regular operation viz., feeding, watering etc. Mortality was recorded as and when occurred. Mortality rate (\%) was calculated from the records of dead birds up to end of the study against total number of birds.

\section{Economics}

Relative economics was calculated by subtracting the cost of feeding from the output of bird sold at ₹ 70 per kg live weight. Garlic used for experimental feeding was purchased at ₹ 60 per $\mathrm{kg}$.

\section{Statistical analysis}

All the recorded and calculated data were subjected to statistical analysis by "factorial and completely randomized design" (FCRD) employing one-way analysis of variance as per Snedecor and Cochran (1994). A p-value of $<0.05$ was considered as significant difference among the treatments groups and the comparison of means were tested as per Duncan's multiple range test (DMRT) described by Duncan (1955).

\section{Results and Discussion}

\section{Body weight}

Average initial body weight (IBW) and corresponding final body weight (FBW) of broiler chicks are presented in Table 1. The body weight of birds were significantly higher $(\mathrm{P}<0.001)$ in garlic supplemented birds as compared to without supplemented control 
birds. When the diet of birds were supplemented with $0.1 \%$ garlic powder $\left(\mathrm{T}_{2}\right)$ resulted in higher $(\mathrm{P}<0.001)$ body weight as compared to birds fed with $0.5 \%$ garlic powder $\left(\mathrm{T}_{3}\right)$ and without garlic supplemented control birds $\left(\mathrm{T}_{1}\right)$. Mahmood et al., (2009) and Aji et al., (2011) also supported that garlic supplementation significantly improved body weight. While Rahimi et al., (2011) reported that garlic supplementation had no significant effect on body weight.

\section{Body weight gain}

Total body weight gain was significantly $(\mathrm{P}<0.001)$ higher in $\mathrm{T}_{2}$ as compared to $\mathrm{T}_{3}$ and $\mathrm{T}_{1}$ (Table 1). Earlier studies have reported mixed responses in body weight gain to garlic supplementation. Stanacev et al., (2011) and Suriya et al., (2012) reported that garlic supplementation significantly improved body weight gain. In present study, better weight gain in $T_{2}$ might be due to the action of allicin which inhibits the growth of pathogenic bacteria by interfering with bacterial cell metabolism (Ghosh et al., 2010). Apart from this, garlic also enhances pancreatic enzymes activity (Ramakrishna et al., 2003) and activates the digestive process which improves absorption of nutrients and ultimately the growth.

\section{Feed intake}

Total feed intake was significantly $(\mathrm{P}<0.05)$ better in birds receiving $0.1 \%$ garlic $\left(\mathrm{T}_{2}\right)$ as compared to birds that are receiving either 0.5 $\%$ garlic $\left(\mathrm{T}_{3}\right)$ or control (Table 1). Slight reduction in feed intake at higher doses might be due to increasing repulsive odour and taste of garlic (Pourali et al., 2010). Javandel et al., (2008) reported that feed consumption was significantly higher in birds fed diets with lower concentration of garlic 0.125 and 0.25 $\%$ as compared to higher level $0.5,1$ and $2 \%$. Similar findings were also reported by Mansoub and Myandoab (2011). In contrast, Rahimi et al., (2011) reported non-significant effect of garlic supplementation on feed intake in broilers.

Table.1 Growth performance of broilers fed different levels of garlic

\begin{tabular}{|c|c|c|c|c|}
\hline Parameters & & Treatments & & P Value \\
\hline & $\mathbf{T}_{1}$ & $\mathbf{T}_{2}$ & $\mathbf{T}_{3}$ & \\
\hline IBW (g) & $42.28 \pm 0.31$ & $42.27 \pm 0.32$ & $42.18 \pm 0.33$ & NS \\
\hline FBW (g) & $2013.69 \pm 6.89^{\mathrm{a}}$ & $2097.02 \pm 5.86^{c}$ & $2039.95 \pm 3.77^{b}$ & $0.001 * * *$ \\
\hline BWG (g) & $1971.50 \pm 6.92^{\mathrm{a}}$ & $2054.70 \pm 5.77^{c}$ & $1997.70 \pm 3.68^{b}$ & $0.001 * * *$ \\
\hline FI $(g)$ & $3461.10 \pm 36.69^{\mathrm{a}}$ & $3615.70 \pm 8.8^{\mathrm{b}}$ & $3514.70 \pm 50.46^{\mathrm{b}}$ & $0.041 *$ \\
\hline FCR & $1.82 \pm 0.01^{b}$ & $1.76 \pm 0.01^{a}$ & $1.79 \pm 0.01^{\mathrm{ab}}$ & $0.017 *$ \\
\hline
\end{tabular}

Means with different superscripts in a row differ significantly.

$*(\mathrm{P}<0.05) * *(\mathrm{P}<0.01) * * *(\mathrm{P}<0.001)$ NS- non-significant

IBW: Initial Body Weight, FBW: Final Body weight, BWG: Body Weight Gain, FI: Feed Intake, FCR: Feed Conversion Ratio 
Table.2 Economics of feeding different levels of garlic

\begin{tabular}{|l|c|c|c|c|}
\hline Parameters & & Treatments & P Value \\
\hline Feed cost $(₹) / \mathbf{k g}$ live broiler & $\mathbf{T}_{\mathbf{1}}$ & $\mathbf{T}_{\mathbf{2}}$ & $\mathbf{T}_{\mathbf{3}}$ & \\
\hline Total cost $(₹) / \mathbf{k g}$ live broiler & $48.03 \pm 0.40^{\mathrm{b}}$ & $46.74 \pm 0.20^{\mathrm{a}}$ & $47.92 \pm 0.24^{\mathrm{b}}$ & $\mathbf{0 . 0 2 2} *$ \\
\hline Total cost $(₹) / \mathbf{k g}$ meat & $67.34 \pm 0.45^{\mathrm{b}}$ & $65.90 \pm 0.22^{\mathrm{a}}$ & $67.22 \pm 0.27^{\mathrm{b}}$ & $\mathbf{0 . 0 2 3}$ \\
\hline Total cost $(₹)$ of production/broiler & $90.51 \pm 0.60^{\mathrm{b}}$ & $87.67 \pm 0.29^{\mathrm{a}}$ & $89.90 \pm 0.36^{\mathrm{b}}$ & $\mathbf{0 . 0 0 3} * *$ \\
\hline
\end{tabular}

Means with different superscripts in a row differ significantly.

$*(\mathrm{P}<0.05) * *(\mathrm{P}<0.01) * * *(\mathrm{P}<0.001) \mathrm{NS}-$ non-significant

\section{Feed conversion ratio}

The better feed conversion ratio $(\mathrm{P}<0.05)$ was observed in $\mathrm{T}_{2}$ as compared to $\mathrm{T}_{3}$ and $\mathrm{T}_{1}$ (Table $1)$. Results of the present study are in agreement with previous findings of Fadlalla et al., (2010) and Suriya et al., (2012). On the other hand, Aji et al., (2011) reported non-significant effect of garlic on feed conversion ratio. In the present study better FCR in garlic supplemented group might be due to control of the growth and colonization of various pathogenic microorganisms in the gut leading to enhanced efficiency of utilization of feed. Thus, better FCR in $T_{2}$ may be due to nutrient sparing effect of garlic.

\section{Mortality}

Out of 180 chicks reared only 3 chicks were died during entire experiment period indicating that the mortality (\%) was well within the normal limit. Total mortality $(\%)$ was 1.67 in all the treatment groups with 3.33, 0.00 and 1.67 in $\mathrm{T}_{1}, \mathrm{~T}_{2}$ and $\mathrm{T}_{3}$ experimental groups, respectively. The results of the present study were supported by the earlier findings of Fadlalla et al., (2010). In present study, lower mortality in garlic fed birds may be due to antimicrobial action of garlic

\section{Economics of feeding}

Economics of garlic supplementation at various levels is presented in Table 2. The Feed cost $(₹) / \mathrm{kg}$ live broiler, Total cost (₹)/kg live broiler was significantly $(\mathrm{P}<0.05)$ lower in $\mathrm{T}_{2}$ as compare to $\mathrm{T}_{3}$ and $\mathrm{T}_{1}$. Total cost $(₹) / \mathrm{kg}$ meat was significantly $(\mathrm{P}<0.001)$ lower in $\mathrm{T}_{2}$ as compare to $T_{3}$ and $T_{1}$. Lowered cost of production in garlic supplemented group is mainly because of better feed conversion ratio due to garlic's growth promoting effect. In contrary to present findings, Aji et al., (2011) reported increased feed cost when birds were supplemented with garlic as compared to control.

It could be concluded that $0.1 \%$ garlic supplemented group had significantly higher growth rate and better economic benefit than $0.5 \%$ garlic supplemented group and control. Garlic at $0.1 \%$ is an economical alternative to antibiotic growth promoters and can be easily made and adopted by the poultry farmers.

\section{Acknowledgments}

Authors thank the University authorities of SDAU, Sardarkrushinagar and Head Alpha poultry farm for facilities provided and cooperation extended for this work.

\section{References}

Aji, S.B., Ignatius, Th., Ado, Y.A., Nuhu, J.B., Abdulkarim, A., Aliyu, U., Gambo, M.B., Ibrahim, M.A., Abubakar, H., Bukar, M.M, Imam, H.M. and Numan, P.T. (2011). Effects of feeding onion and garlic on some performance characteristics of broiler chickens. Res. $J$. Poult. Sci., 4(2): 22-27.

Demir, E., Sarica, S., Ozcan, M.A. and 
Suicmez, M. (2003). The use of natural feed additives as alternatives for an antibiotic growth promoter in broiler diets. Br. Poult. Sci., 44: 544-45.

Duncan, D.B. (1955). Multiple Ranges and Multiple F Test. Biometrics, 1: 1-42.

Fadlalla, L.M.T., Mohammed, B.H. and Bakhiet, A.O. (2010). Effect of feeding garlic on the performance and immunity of broilers. Asian J. Poult. Sci., 4(4): 18289.

Ghosh, S., Mehla, R.Th., Sirohi, S.Th., Tomar, S.Th. and Roy, B. (2010). Performance of crossbred calves with dietary supplementation of garlic extract. Indian J. Anim. Sci., 80(7): 690-692.

Javandel, F., Navidshad, B., Seifdavati, J., Pourrahi, G.H. and Baniyaghoub, S. (2008). The favorite dosage of garlic meal as a feed additive in broiler chickens ratios. Pak. J. Biol. Sci., 11: 1746-49.

Karangiya, V.K., Savsani, H.H., Patil, S.S., Garg, D.D., Murthy, K.S., Ribadiya, N.K. and Vekariya, S.J. (2016) Effect of dietary supplementation of garlic, ginger and their combination on feed intake, growth performance and economics in commercial broilers. Veterinary World, 9(3): 245-250.

Mahmood, S., Mushtaq-ul-Hassan, M., Alam, M. and Ahmed, F. (2009). Comparative efficacy of Nigella sativa and Allium sativum as growth promoters in broilers. Int. J. Agric. Biol., 11: 775-78.

Mansoub, N.H. (2011). Comparative effects of using garlic as probiotic on performance and serum composition of broiler chickens. Ann. Biol. Res., 3: 486-490.

Mansoub, N.H. and Myandoab, M.H. (2011). Comparative effect of using Zizaphora
(Thymus valgaris), garlic and probiotic on performance and serum composition of broiler chickens. Ann. Biol. Res., 4: 37378.

NRC. (1994). Nutrient requirements of poultry. 9th revised edition, Subcommittee on poultry nutrition, National Research Council, Washington D.C.

Pourali, M., Mirghelenj, S.A. and Thermanshahi, H. (2010). Effects of garlic powder on productive performance and immune response of broiler chickens challenged with Newcastle disease virus. Glob. Vet., 4(6): 616-621.

Rahimi, S., Teymouri, Z.Z., Tharimi, T.M.A., Omidbaigi, R. and Rokni, H. (2011). Effect of the three herbal extracts on growth performance, immune system, blood factors and intestinal selected bacterial population in broiler chickens. $J$. Agric. Sci. Technol., 13: 527-39.

Ramakrishna, R.R., Platel, Th. and Srinivasan, Th. (2003). In vitro influence of species and spice active principles on digestive enzymes of rat pancreas and small intestine. Nahrung, 47: 408-12.

Snedecor, G.W. and Cochran, W.G. (1994). Statistical Methods, 8th edn. Affiliated East-West press Pvt. Ltd., New Delhi, India.

Stanacev, V., Glamocic, D., Milosevic, N., Puvaca, N., Stanacev, V. and Plavsa, N. (2011). Effect of garlic (Allium sativum) in fattening chick's nutrition. Afr. $J$. Agric. Res., 6(4): 943-48.

Suriya, R., Zulkifli, I. and Alimon, A.R. (2012). The effect of dietary inclusion of herbs as growth promoter in broiler chickens. $J$. Anim. Vet. Adv., 11(3): 346- 50.

\section{How to cite this article:}

Makwana, R.B., S.S. Parikh, B.D. Savaliya, J.A. Chavda, C.N. Jadav and Patel, H.A. 2019. Studies on Feed Intake, Growth Performance and Economics of Broilers Fed Garlic Powder. Int.J.Curr.Microbiol.App.Sci. 8(08): 2026-2030. doi: https://doi.org/10.20546/ijcmas.2019.808.236 